\title{
GoAL-ORIENTEd FACTORY PlanNING Considering A LEAN PRODUCTION SYSTEM
}

\author{
PALLUCK, M.; DOMBROWSKI, U. \& HENNERSDORF, S.
}

Abstract: Goals, methods and tools of an (Lean Production System) LPS are always chosen considering the corporate goals. At the same time goals for factory planning are defined. To guarantee an integrated approach the goals for factory planning have to be aligned with the corporate goals and the goals of an LPS. Furthermore the factory elements have to be designed in order to fulfil the purposes of the production system in the best possible way. Hence in literature as well as in practice only a few approaches are addressing this fact to a minor degree, the following article presents an integrated model for a corporate goal-oriented factory planning by using a process as well as a qualification and design module. Altogether this paper offers answers to the following questions: "How does the implementation of LPS elements affect the elements of a factory?" and "How can the implementation process of an LPS be aligned with the process of factory planning?".

Key words: corporate goals, factory planning, lean production
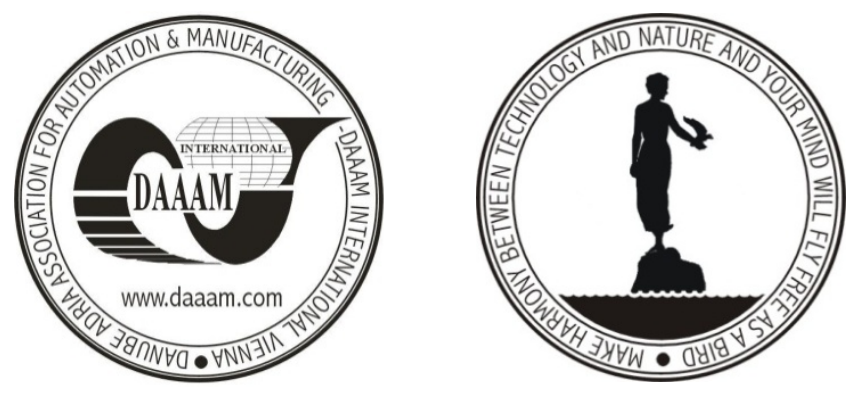

Authors' data: Dipl.-Wirtsch.-Ing. Palluck, M[arkus]; Univ.-Prof. Dr.-Ing. Dombrowski, U[we]; Dipl.-Wirtsch.-Ing. Hennersdorf, S[ibylle], Institute for Production Management and Operations Research, Technical University of Braunschweig, Langer Kamp 19, Braunschweig, Germany, m.palluck@tu-bs.de, u.dombrowski@tu-bs.de, s.hennersdorf@tu-bs.de

This Publication has to be referred as: Palluck, M[arkus]; Dombrowski, U[we] \& Hennersdorf, S[ibylle] (2009). Goal-Oriented Factory Planning Considering a Lean Production System, Chapter 17 in DAAAM International Scientific Book 2009, pp. 151-160, B. Katalinic (Ed.), Published by DAAAM International, ISBN 978-3901509-69-8, ISSN 1726-9687, Vienna, Austria

DOI: $10.2507 /$ daaam.scibook.2009.17 